\title{
GAMBARAN FAKTOR UMUR DAN PARITAS IBU YANG MEMILIKI BAYI DENGAN BBLR DI WILAYAH KECAMATAN SINGAPARNA KABUPATEN TASIKMALAYA TAHUN 2014.
}

Oleh :

DR. Setiawan, SH, M.Kes

Annisa Rahmidini, SST, M.Keb

\section{A. Abstrak}

Menurut WHO, pada tahun 2005 hampir semua (88\%) dari 5 juta kematian neonatal berada di negara berkembang atau berpenghasilan rendah. Lebih dari dua per tiga kematian adalah BBLR yaitu berat badan lahir kurang dari 2500 gram. Secara global diperkirakan terdapat 25 juta persalinan per tahun dimana $17 \%$ diantaranya adalah BBLR dan hampir semua terjadi di negara berkembang (Hadi, 2001). Berdasarkan data yang didapatkan di wilayah Puskesmas Singaparna terdapat 44 Bayi dengan BBLR. Tujuan dari penelitian ini adalah mengetahui gambaran umur dan paritas ibu yang memiliki Bayi dengan BBLR di wilayah kerja Puskesmas Singaparna tahun 2014.

Penelitian ini merupakan penelitian kuantitatif dengan rancangan penelitian diskriptif yaitu membuat gambaran atau deskriptif. Populasi penelitian ini adalah semua bayi baru lahir dengan berat badan lahir rendah (BBLR) di Puskesmas Singaparna. Jumlah populasi dalam penelitian ini adalah 44 bayi BBLR. Tehnik pengambilan sampel secara simple random sampling. Jumlah sampel sebanyak 44 bayi BBLR Instrumen penelitian adalah lembar observasi yang bersumber pada rekam medik pasien laporan puskesmas Singaparna.

Hasil penelitian menyatakan bahwa mayoritas usia ibu yang memiliki BBLR adalah usia kurang dari 20 tahun dan lebih dari 35 tahun yaitu 25 orang atau 56.8\%. Serta mayoritas paritas ibu yang memiliki BBLR adalah primipara yaitu 30 orang (68.2\%)

Melihat hasil dari penelitian ini peneliti memberikan saran kepa calon pengantin untuk memperhatikan usia reproduksi sehat pada saat akan melakukan program hamil. Serta pengaturan jumlah anak dan jarak kelahiran juga turut diperhatikan karna dapat berkontribusi dalam kejadian BBLR.

Kata Kunci: usia, paritas, BBLR 


\section{B. Latar Belakang}

Angka kematian bayi di Indonesia saat ini masih tergolong tinggi disbanding dengan Negara-negara di ASEAN. Angka kematian bayi di Indoesia tercatat 36 per 1000 kelahiran hidup pada tahun 2006. Penyebab kematian bayi terbanyak adalah karena gangguan perinatal. Sekitar $2-27 \%$ kematian perinatal disebabkan karena kelahiran bayi berat lahir rendah (BBLR). Sementara itu prevalensi BBLR pada saat ini diperkirakan 7 $14 \%$ yaitu sekitar $459.200-900.000$ bayi (Depkes RI, 2005).

Bayi berat lahir rendah dapat mengalami gangguan mental dan fisik pada usia tumbuh kembang, sehingga membutuhkan biaya perawatan yang tinggi (Anonim, 2006). BBLR adalah salah satu akibat dari ibu hamil yang menderita energi kronis (KEK) (Depkes RI, 2005).

Menurut WHO, pada tahun 2005 hampir semua (88\%) dari 5 juta kematian neonatal berada di negara berkembang atau berpenghasilan rendah. Lebih dari dua per tiga kematian adalah BBLR yaitu berat badan lahir kurang dari 2500 gram. Secara global diperkirakan terdapat 25

\section{Metode}

Penelitian ini merupakan penelitian kuantitatif dengan rancangan penelitian diskriptif yaitu membuat gambaran atau deskriptif tentang suatu keadaan secara obyektif kemudian dengan

melakukan pengukuran terhadap variabel penelitian kemudian mencari hubungan antara variabel dan menguji hipotesa yang telah dirumuskan (Sastroasmoro, 2002).

Populasi penelitian ini adalah semua bayi baru lahir dengan berat badan lahir juta persalinan per tahun dimana $17 \%$ diantaranya adalah BBLR dan hampir semua terjadi di negara berkembang (Hadi, 2001).

Berdasarkan data indikator kesehatan proporsi BBLR pada tahun 2000 berkisar antara 0,91\% Faktorfaktor yang menyebabkan terjadinya BBLR antara lain kurangnya gizi pada ibu hamil, ibu hamil perokok, ibu hamil pekerjaberat, sosial ekonomi rendah dan faktor janin (Prawirohardjo, 2002). Joeharno (2008), menambahkan, bahwa BBLR juga dapat terjadi pada ibu dengan paritas tinggi. Ibu dengan

paritas tinggi berisiko (50\%) melahirkan bayi dengan berat lahir yang rendah. BBLR merupakan masalah kesehatan yang cukup menonjol di Indonesia, karena pada bayi BBLR mempunyai angka mortalitas dan morbiditas yang tinggi.

Berdasarkan data yang didapatkan di wilayah Puskesmas Singaparna terdapat 44 Bayi dengan BBLR. Berdasarkan data tersebut peneliti bermaksud untuk melakukan penelitian dengan judul gambaran faktor umur dan paritas ibu dengan bayi BBLR di Wilayah Kecamatan Singaparna Kabupaten Tasikmalaya tahun 2014.

rendah (BBLR) di Puskesmas Singaparna. Jumlah populasi dalam penelitian ini adalah 44 bayi BBLR. Tehnik pengambilan sampel secara simple random sampling. Jumlah sampel sebanyak 44 bayi BBLR Instrumen penelitian adalah lembar observasi yang bersumber pada rekam medik pasien laporan puskesmas Singaparna. 


\section{Hasil Penelitian}

Berdasarkan hasil penelitian didapatkan bahwa :

1. Gambaran umur ibu yang memiliki bayi dengan BBLR

Tabel

Distribusi frekwensi umur ibu yang memiliki bayi dengan BBLR

\begin{tabular}{|l|l|c|c|}
\hline No & \multicolumn{1}{|c|}{ Kategori } & F & \% \\
\hline 1 & $\begin{array}{l}<20 \text { tahun dan lebih } \\
\text { dari } 35 \text { tahun } \\
2\end{array}$ & 25 & 56.8 \\
\hline & \multicolumn{1}{|c|}{ Jumlah } & 19 & 43.25 \\
\hline
\end{tabular}

Berdasarkan tabel diatas didapatkan bahwa mayoritas usia ibu yang memiliki BBLR adalah usia kurang dari 20 tahun dan lebih dari 35 tahun yaitu 25 orang atau 56.8\%.

2. Gambaran paritas ibu yang memiliki bayi dengan BBLR

\section{Tabel}

Distribusi frekwensi paritas ibu yang memiliki bayi dengan BBLR

\begin{tabular}{|l|l|c|c|}
\hline No & Kategori & F & \% \\
\hline 1 & Primipara & 30 & 68.2 \\
2 & Multipara & 14 & 31.8 \\
3 & Grandepara & 0 & 0 \\
& & & $\mathbf{1 0 0}$ \\
\hline & Jumlah & $\mathbf{4 4}$ & \\
\hline
\end{tabular}

Berdasarkan tabel diatas didapatkan bahwa mayoritas paritas ibu yang memiliki BBLR adalah primipara yaitu 30 orang $(68.2 \%)$

\section{E. Pembahasan}

Paritas ibu berhubungan dengan beratbadan bayi lahir rendah, dimana paritas Primipara mempunyai risiko sebesar 3,6 untuk melahirkan bayi dengan BBLR..

Berdasar hasil penelitian, ibu dengan paritas primipara sebanyak $68,2 \%$ responden melahirkan BBLR. Hasil ini sesuai dengan penelitian Barends (2005), bahwa paritas 0 dan paritas lebih atau sama dengan 4 mempunyai risiko lebih besar dibanding paritas 1, 2 dan 3 yang melahirkan BBLR.

Hasil penelitian ini menyanggah penelitian Istiyarsi (2000) di Kabupaten Magelang, dimana paritas tinggi mempunyai risiko $10,2 \mathrm{kali}$ untuk melahirkan BBLR. Demikian pula dengan penelitian Marsianto dan Syamsuri (1997), bahwa ibuprimigravida mempunyai risiko lebih rendah untuk melahirkan bayi dengan berat badan lahir rendah bila dibandingkan dengan multigravida

\section{F. Simpulan dan saran}

Berdasarkan tabel diatas didapatkan bahwa mayoritas usia ibu yang memiliki BBLR adalah usia kurang dari 20 tahun dan lebih dari 35 tahun yaitu 25 orang atau $56.8 \%$.

Berdasarkan tabel diatas didapatkan bahwa mayoritas paritas ibu yang memiliki BBLR adalah primipara yaitu 30 orang (68.2\%) 


\section{G. Referensi}

Anonim, 2006. Faktor-faktor yang Mempengaruhi Kejadian BBLR. http:// www.jiptunair.com diakses Tanggal 23 Januari 2009 Jam $11.00 \mathrm{WIB}$

Depkes RI, 2001, Standar Pelayanan Kebidanan, Jakarta.

2005, Asuhan

Kesehatan Anak Dalam Konteks Keluarga, Jakarta.

Dewi, M., 2003, Kehamilan dengan Risiko BBLR di Desa Tlogorejo, Yogyakarta,KTI, Yogyakarta

Hincliff,Sue, 2002, Kamus Keperawatan, Edisi 17, Jakarta Ibrahim, 2002, Perawatan Kebidanan Jilid I, EGC, Jakarta.

Istiyarsi, 2000, Menanti Buah Hati, Media Pressindo, Jakarta
Joeharno. 2008. Beberapa Faktor Risiko Kejadian BBLR di Rumah Sakit Al

Fatah Ambon Perode Januari -

Desember Tahun 2006. KTI. Jakarta

Lubis, 2003, Status Gizi Ibu Hamil serta Pengaruhnya terhadap Bayi yang Dilahirkan. http://www.depkes.go.id, diakses tanggal 23 Maret 2008

Manuaba, 2002, Ilmu Kebidanan Penyakit Kandungan dan Keluarga Berencana I,

EGC, Jakarta.

Marsianto dan Syamsuri, 1999, Faktor Risiko Terjadinya Bayi Berat Badan Lahir Rendah

(BBLR), Berita Kedokteran

Masyarakat, Yogyakarta

Mochtar, R., 2002, Sinopsis Obstetri, EGC, Jakarta 